\title{
SISTEM INFORMASI PENGELOLAAN DATA NILAI SISWA PADA SD NEGERI JAMBANGAN 1 KABUPATEN NGAWI
}

\author{
Dimas Aryo Anggoro ${ }^{1}$, Yanuar Eko Adi Lukmana ${ }^{2}$ \\ ${ }^{1,2}$ Program Studi Informatika, Fakultas Komunikasi dan Informatika, \\ Universitas Muhammadiyah Surakarta \\ e-mail : ${ }^{1}$ dimas.a.anggoro@ums.ac.id, ${ }^{2}$ yanuare9@gmail.com
}

\begin{abstract}
Abstrak
Nilai siswa merupakan representasi hasil belajar siswa yang ditepuh dalam satu semester. Nilai akhir siswa diambil dari hasil pengolahan beberapa nilai siswa. SD Negeri Jambangan 1 merupakan sekolah dasar negeri yang pengolahan data nilai siswanya dilakukan secara manual dengan menggunakan Microsoft Excel serta dokumentasi pembukuan. Pengolahan data nilai siswa dengan cara manual dapat menimbulkan beberapa resiko seperti rusak dan hilangnya data nilai siswa. Sistem informasi pengolahan data nilai siswa dikembangkan dengan tujuan mengurangi resiko rusak dan hilangnya data serta mempermudah proses pengolahan data. Sistem ini akan dibangun berbasis website menggunakan model pengembangan Software Development Life Cycle (SDLC) dengan metode Waterfall. Tahapan penelitian berupa analisis kebutuhan, perancangan, implementasi, pengujian dan perawatan. Pengujian sistem ini dilakukan dengan metode Black Box untuk menguji fungsionalitas sistem serta User Acceptance Testing (UAT) untuk menguji sistem apakah sistem mampu memenuhi kebutuhan user. Hasil pengujian black box menyatakan sistem ini sudah layak di gunakan. Hasil pengujian UAT didapatkan 96,42\% responden setuju sistem ini dapat memudahkan dan mempercepat pihak sekolah dalam mengelola dan mengolah data nilai siswa. Penelitian ini menghasilkan sebuah sistem yang dapat mengolah data siswa dari data nilai dasar hingga menjadi nilai akhir siswa.
\end{abstract}

Kata kunci: nilai siswa, pengelolaan nilai siswa, sekolah, waterfall

\section{PENDAHULUAN}

Sekolah Dasar Negeri Jambangan 1 merupakan sekolah dasar negeri yang terletak di Kecamatan Paron Kabupaten Ngawi. Sekolah ini memiliki reputasi bagus dengan fasilitas sekolah yang lengkap serta banyaknya lulusan siswa yang berprestasi. Namun sekolah ini masih memiliki kelemahan dalam mengelola data. Salah satunya yaitu data nilai siswa.

Prosedur pengolahan data nilai siswa di sekolah ini masih dilakukan dengan cara konvensional. Guru mata pelajaran menyampaikan nilai siswa kepada kepada guru wali kelas dalam bentuk lembaran kertas kemudian guru wali kelas menuliskan hasil nilai ke dalam rapor. Rapor akan dibagikan kepada masing-masing siswa dan diminta untuk mengembalikani ke sekolah dalam rentang waktu tertentu. Biasanya dua sampai tiga minggu. Selain menuliskan nilai ke rapor, guru wali kelas juga menyampaikan hasil nilai kepada Tata Usaha Sekolah atau biasa di sebut operator sekolah untuk disimpan dalam file Microsoft Word dan Microsoft Excel yang kemudian diolah dan dilaporkan kepada kepala sekolah. Dari prosedur yang dilakukan, terdapat resiko terhadap rusak dan hilangnya data yang diakibatkan oleh rusaknya sumber penyimpanan nilai yang dilakukan secara konvensional dan offline. Resiko lain yang dihadapi adalah lambatnya pencarian data nilai siswa.

Rivai dan Purnama [1] menyampaikan bahwa pengembangan sistem informasi pengelolaan data nilai siswa dapat memudahkan wali kelas dalam memperoleh informasi rekap nilai siswa serta dapat menampilkan data nilai jika dibutuhkan sewaktu-waktu. Selain itu, Wardani [2] menyebutkan dengan dikembangkannya sistem pengolahan nilai, Sekolah 
mendapat kemudahan dalam mengelola data nilai dan dapat mengurangi resiko kesalahan dalam penulisan nilai.

Sistem Informasi Pengolahaan Data Nilai Siswa pada SD Negeri Jambangan 1 Ngawi dikembangkan berbasis website menggunakan model Software Development Life Cycle (SDLC) dengan metode Waterfall. Untuk pemodelan sistem menggunakan Unified Modelling Language (UML) berupa Use Case Diagram dan Activity Diagram.

Sistem Informasi ini dikembangkan dengan tujuan memudahkan pihak sekolah dalam mengelola, mengolah dan mencari data nilai siswa dan mengurangi resiko kehilangan data nilai. Adapun luaran dari sistem informasi ini adalah berupa rapor siswa.

\section{METODE}

Metode yang digunakan dalam penelitian ini adalah Software Development Life Cycle (SDLC) dengan pendekatan model Waterfall. Model ini menekankan penelitian sebelum pengembangan sehingga mengurangi kecacatan desain [7]. Selain itu, dokumentasi dan perencanaan yang intensif mendukung pengembangan sistem dengan kontrol kualitas sebagai fokus utama. Metode Waterfall digunakan karena mudah dipahami dan diimplementasikan serta bekerja dengan baik pada produk matang [8]. Metode ini memiliki beberapa tahapan seperti pada Gambar 1.

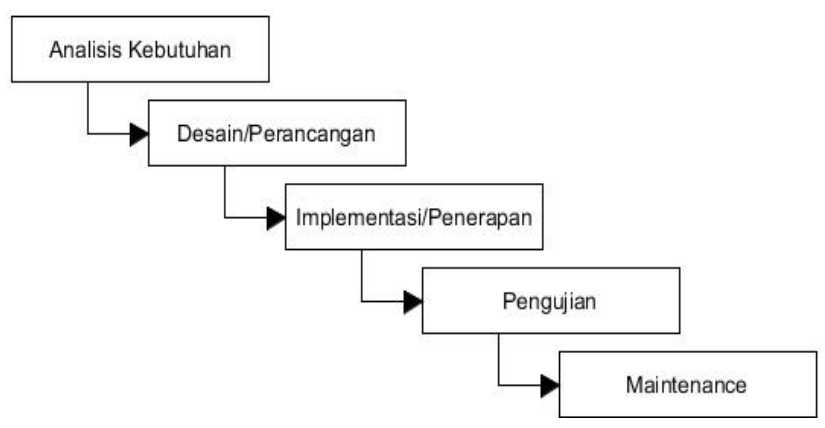

Gambar 1. Diagram alur metode Waterfall.

\section{a. Analisis Kebutuhan}

Analisis kebutuhan diperlukan dalam menentukan spesifikasi Sistem Informasi pengelolaan data nilai siswa SD Negeri Jambangan 1 Ngawi. Kebutuhan sistem didefinisikan dengan melakukan wawancara bersama Kepala Sekolah, Wali Kelas dan Admin SD Negeri Jambangan 1 Ngawi. Pihak sekolah membutuhkan sebuah sistem yang membantu pihak sekolah dalam mengelola nilai siswa hingga menjadi rapor siswa dengan format sesuai dengan kurikulum 2013.

\section{b. Desain/Perancangan Sistem}

Pada sistem informasi pengelolaan data nilai siswa ini dirancang menggunakan pemodelan Unified Modelling Language (UML). Unified Modelling Language (UML) merupakan bahasa standar untuk memodelkan, mendeskripsikan, dan mengkomunikasikan suatu sistem dengan memanfaatkan diagram, simbol dan teks pendukung [3,4,5]. Jenis pemodelan UML yang akan digunakan yaitu Use Case Diagram dan Activity Diagram.

1) Use Case Diagram.

Use Case Diagram adalah sebuah pemodelan yang mendeskripsikan hubungan dan perilaku stakeholder terhadap sistem informasi yang akan dikembangkan [3,5,6]. Dalam Use Case Diagram ini user yang bisa menggunakan sistem ini hanya kepala sekolah, wali kelas dan operator/admin. Interaksi antara user dengan sistem ini dapat dilihat pada Gambar 2. 


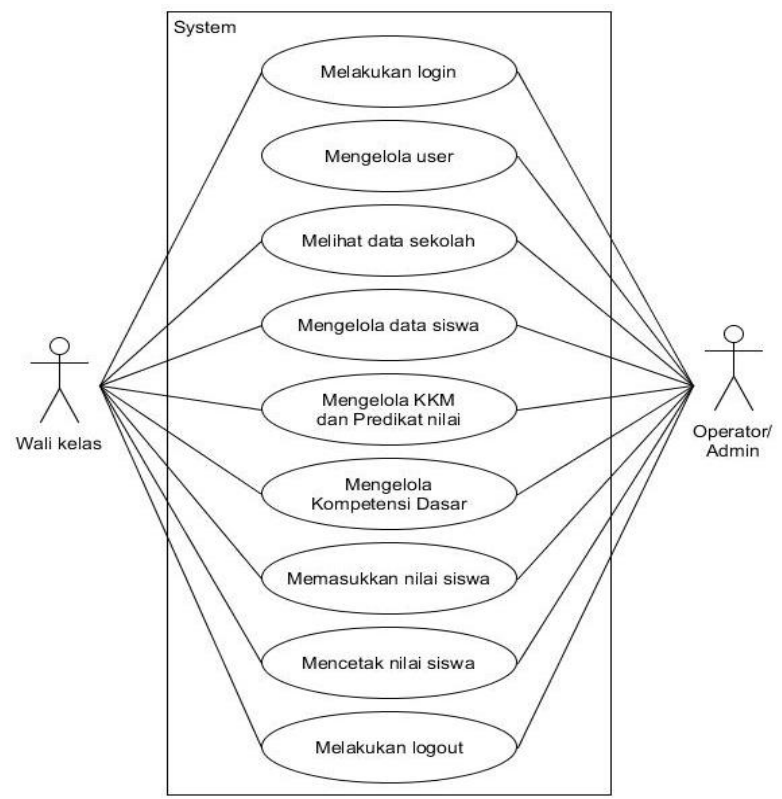

Gambar 2. Diagram Use Case.

Pada sistem ini terdapat 2 kelompok user. User 1 yaitu Wali kelas dan user 2 yaitu operator/admin. Operator/admin dapat melakukan login, mengelola data user, mengelola data siswa, memasukkan nilai siswa, mencetak nilai siswa dan melakukan logout. Sedangkan Wali kelas dapat melakukan login, memasukkan nilai siswa, mencetak nilai siswa dan melakukan logout.

\section{2) Activity Diagram}

Activity Diagram atau diagram aktivitas merupakan pemodelan rangkaian aliran kerja dari aktivitas sebuah sistem yang digunakan untuk mendeskripsikan aktivitas yang dibentuk dalam suatu operasi $[3,5,6]$. Diagram aktivitas tidak menampilkan aktivitas yang dilakukan oleh user, tetapi menampikan aktivitas apa yang bisa dikerjakan oleh sistem. Diagram aktivitas pada sistem ini ditunjukkan pada Gambar 3 dan Gambar 4.

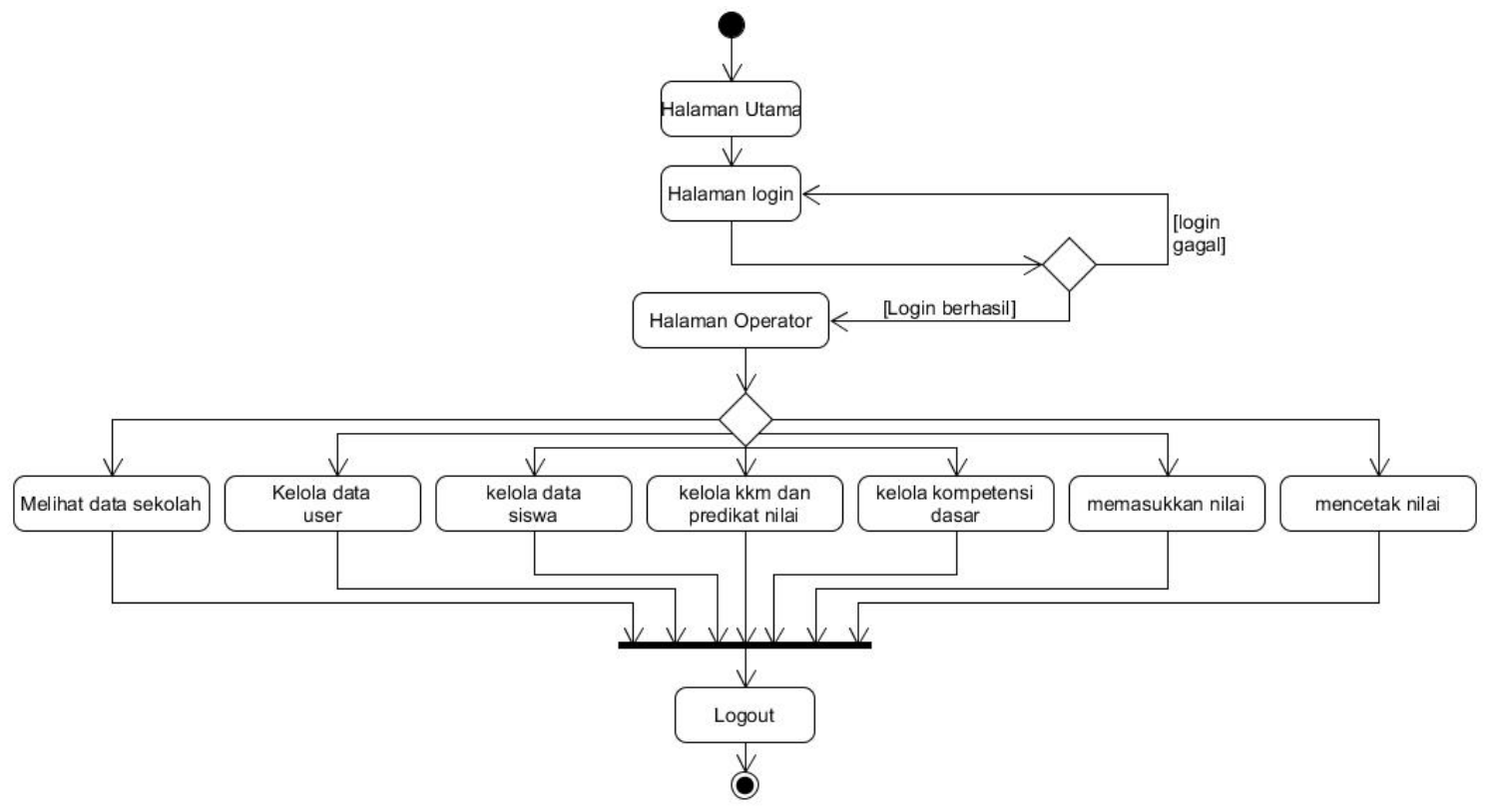

Gambar 3. Diagram aktivitas kepala sekolah dan admin. 


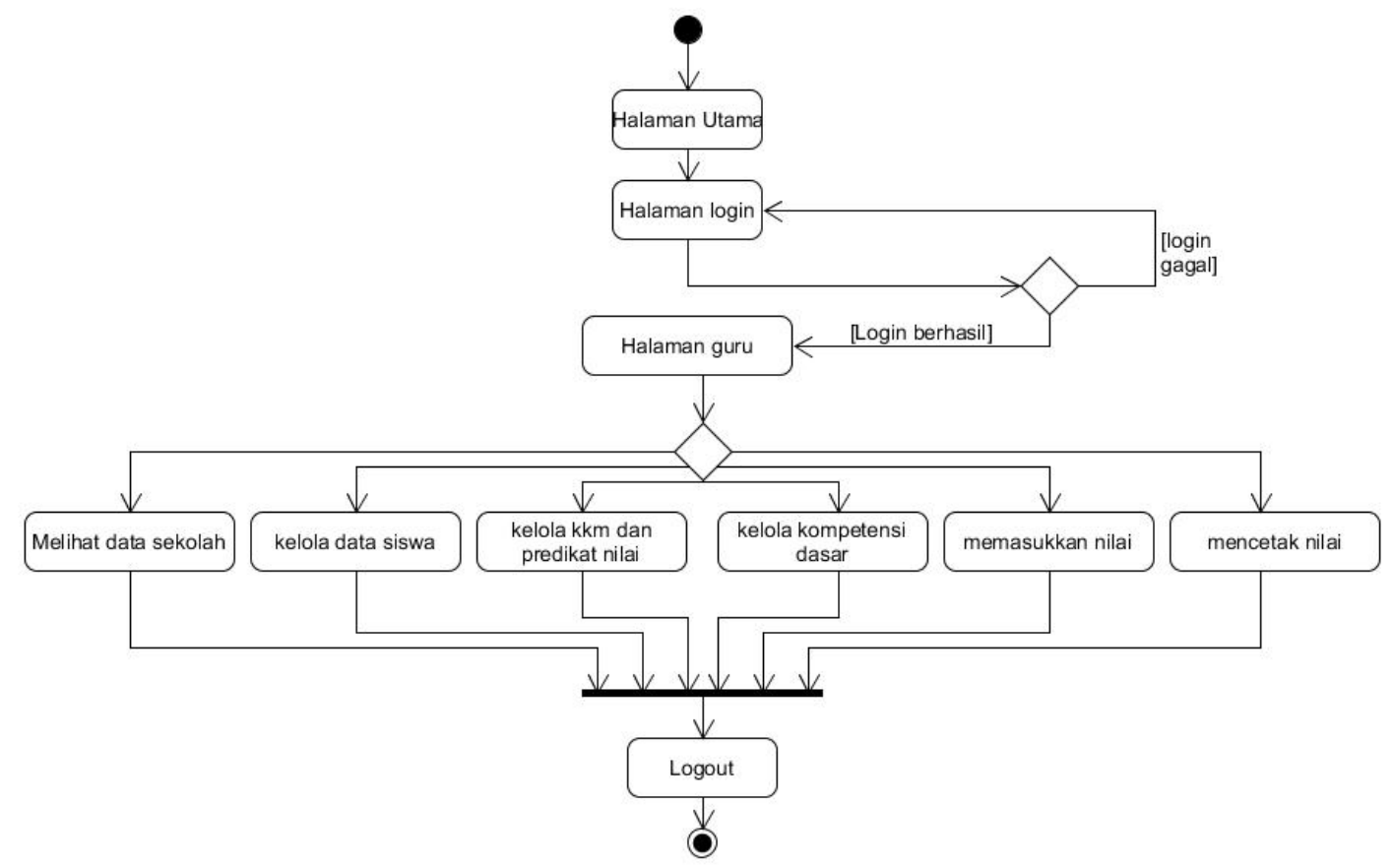

Gambar 4. Diagram aktivitas wali kelas.

\section{c. Penerapan/Implementasi}

Penerapan/Implementasi adalah tahap pengembangan sistem sesuai dengan hasil dari pengolahan analisis kebutuhan dan pemodelan-pemodelan yang telah dilakukan [7]. Dari hasil analisis kebutuhan dan pemodelan, kemudian diimplementasikan dalam bentuk sistem informasi dengan melakukan pengkodingan menggunakan HTML, CSS, Javascript dan PHP, sedangkan basis data yang digunakan adalah MySQL.

\section{d. Pengujian}

Sistem informasi pengelolaan nilai siswa ini dilakukan dengan menggunakan pengujian Black Box dan User Acceptance Testing (UAT). Penggunaan pengujian Black Box untuk mengetahui apakah terdapat kesalahan pada request data dan interface. Pengujian Black Box dimisalkan bahwa penguji hanya mengetahui masukan (input), hasil yang diharapkan serta hasil yang dikeluarkan. Aspek yang diuji adalah melakukan login, menampilkan data, memasukkan data, mengubah data, menghapus data, cetak data dan melakukan logout. Hasil dari pengujian ini berupa status valid atau tidaknya aspek yang diuji serta kesimpulan apakah sistem ini sudah berfungsi sesuai fungsionalitas yang diharapkan [9].

Otaduy dan Diaz [10], UAT dilakukan untuk mengecek apakah suatu system sudah dapat diterima oleh user - memenuhi kebutuhan yang telah diajukan oleh user. Adapun UAT dilakukan dengan membagikan kuesioner kepada user yaitu kepala sekolah, wali kelas dan operator/admin. Kuesioner dibuat untuk mengetahui tanggapan user terhadap sistem. Kuesioner berisi pernyataan-pernyataan mengenai sistem serta jawaban user yang berupa sangat setuju(SS), setuju(S), netral(N), tidak setuju(TS), dan sangat tidak setuju(STS).

\section{e. Maintenance}

Perawatan sistem atau Maintenance dilakukan oleh operator/admin dari SD Negeri Jambangan 1 Ngawi setiap enam bulan sekali. Perawatan meliputi perbaikan sistem apabila ada kecacatan, penambahan fitur ataupun perbaruan data pengguna [11] baik kepala sekolah, wali kelas atau operator/admin. Kecacatan didefinisikan sebagai kesalahan hasil pengolahan data atau kesalahan pengkodean yang berakibat bug pada tampilan halaman [12,13]. 


\section{HASIL DAN PEMBAHASAN}

\section{a. Implementasi Sistem}

Implementasi sistem menunjukkan hasil akhir tampilan dari sistem yang dibangun sesuai dengan tahap perancangan sistem. Sistem ini mempunyai tampilan menu yaitu Halaman Login, Dashboard, Data Admin, Data Sekolah, Data Guru, Data Siswa, KKM Predikat, Data Kompetensi, Kelola Nilai, dan Cetak Rapor.

1) Halaman Login

Halaman ini digunakan sebagai inisiasi untuk masuk dan mengakses menu didalam sistem sistem. Tampilan Halaman login dapat dilihat pada Gambar 5.

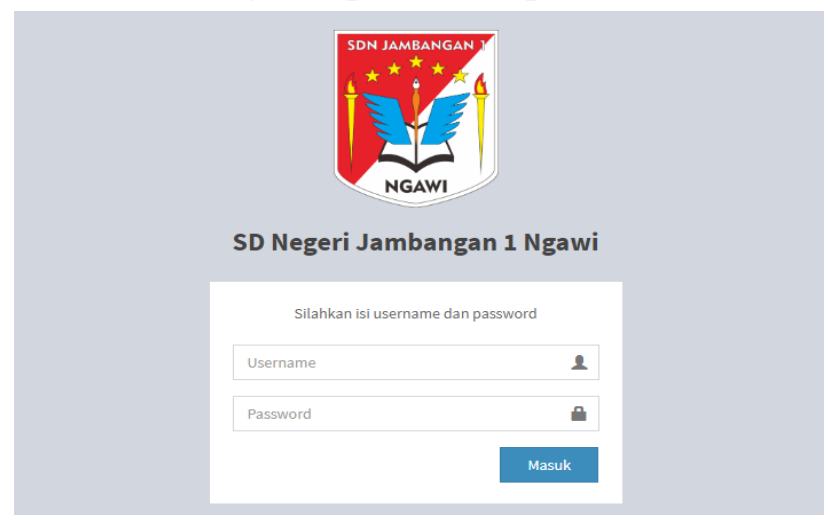

Gambar 5. Halaman Login.

2) Halaman Dashboard

Halaman ini merupakan halaman yang pertama kali ditampilkan setelah pengguna berhasil masuk dari halaman login. Halaman dashboard ditampilkan pada Gambar 6.

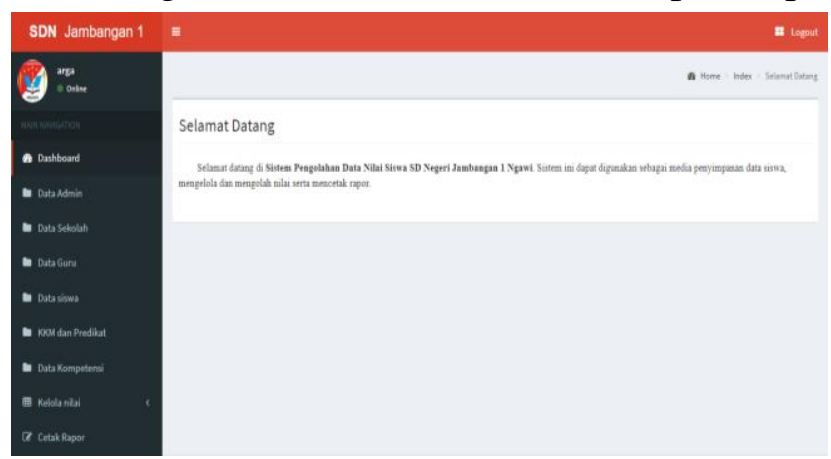

Gambar 6. Halaman Dashboard.

3) Menu Data Admin

Menu Data Admin berisi tentang informasi admin. Menu ini digunakan untuk mengelola username dan password pengguna. Gambar 7 merupakan tampilan Menu Data Admin. 


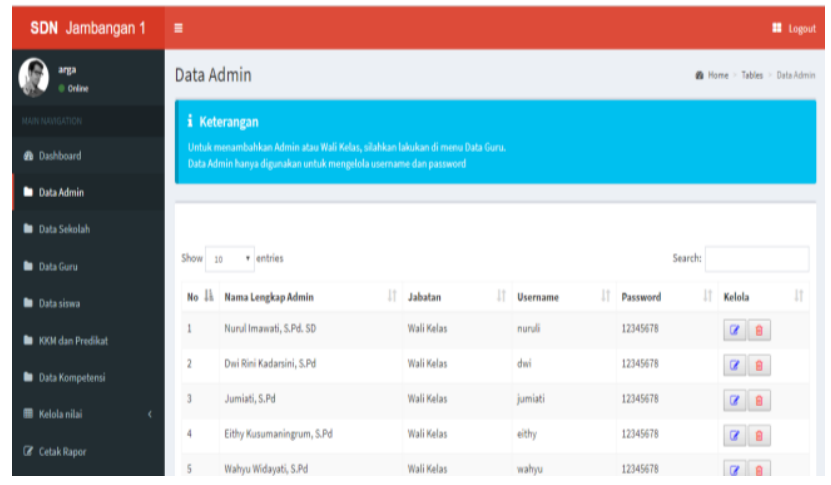

Gambar 7. Menu Data Admin.

4) Menu Data Sekolah

Menu ini menampilkan dan mengelola informasi umum identitas sekolah. Tampilan menu ini dapat dilihat pada Gambar 8.

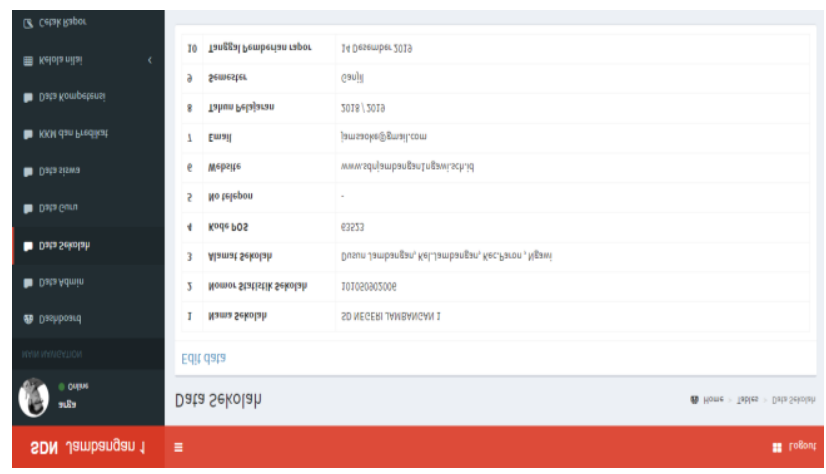

Gambar 8. Menu Data Sekolah.

5) Menu Data Guru

Menu Data Guru berisi informasi tentang guru, admin dan kepala sekolah yang diberi otoritas menggunakan sistem. Data ini bisa ditambahkan, diubah dan dihapus. Tampilan Menu Data Guru disajikan pada Gambar 9.

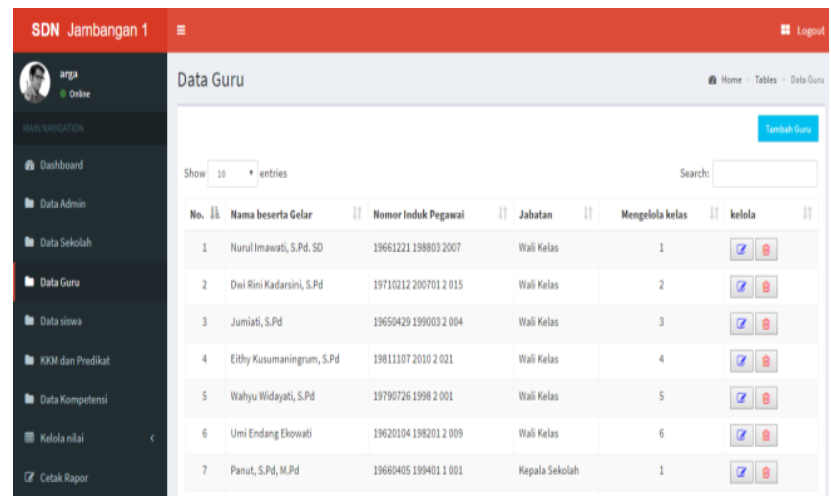

Gambar 9. Menu Data Guru.

6) Menu Data Siswa

Menu ini mengelola keseluruhan data siswa. Data siswa dibagi menjadi tiga bagian yaitu data utama sebagai data yang menjadi acuan sistem, data pelengkap sebagai data tambahan yang diperlukan dalam tampilan rapor, dan kondisi siswa yang berisi data rekapitulasi absensi siswa dan data kondisi fisik siswa. Menu ini dilengkapi fungsi naikkan kelas yang berfungsi untuk menaikkan kelas siswa 1 tingkat diatasnya. Tampilan Menu Data Siswa disajikan pada Gambar 10. 


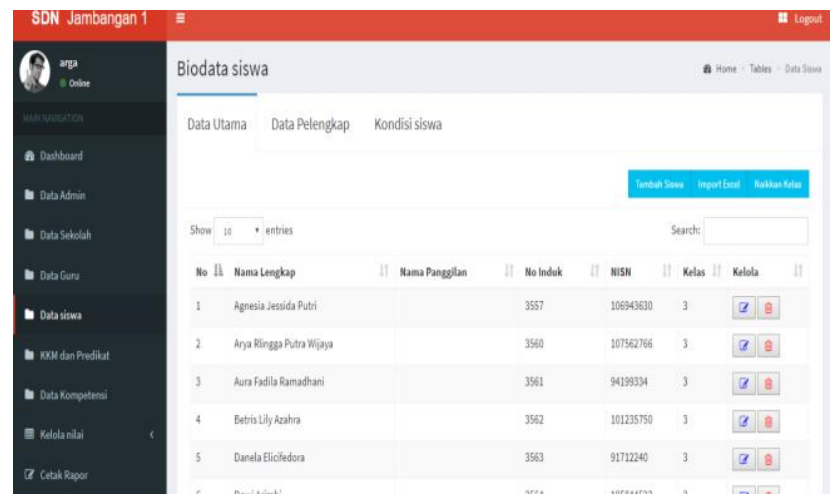

Gambar 10. Menu Data Siswa.

7) Menu KKM Predikat

Menu ini berisi dua bagian yaitu Kriteria Kelulusan Minimal (KKM) dan Predikat Nilai. Pada bagian KKM menampilkan nilai KKM sekolah dan nilai KKM dari masing-masing matapelajaran. Bagian Predikat Nilai berisi tentang sistem penilaian pada nilai siswa. Tampilan menu KKM Predikat ditampilkan pada Gambar 11.

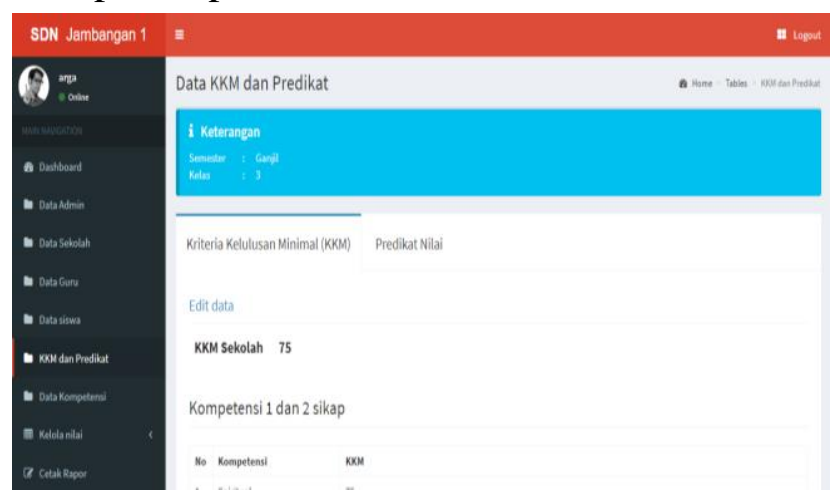

Gambar 11. Menu KKM Predikat.

8) Menu Data Kompetensi

Menu Data Kompetensi berisi kode kompetensi dasar dari setiap mata pelajaran. Data Kompetensi dibagi menjadi tiga bagian sesuai dengan Kompetensi Inti. Tampilan menu Data Kompetensi ditampilkan pada Gambar 12.

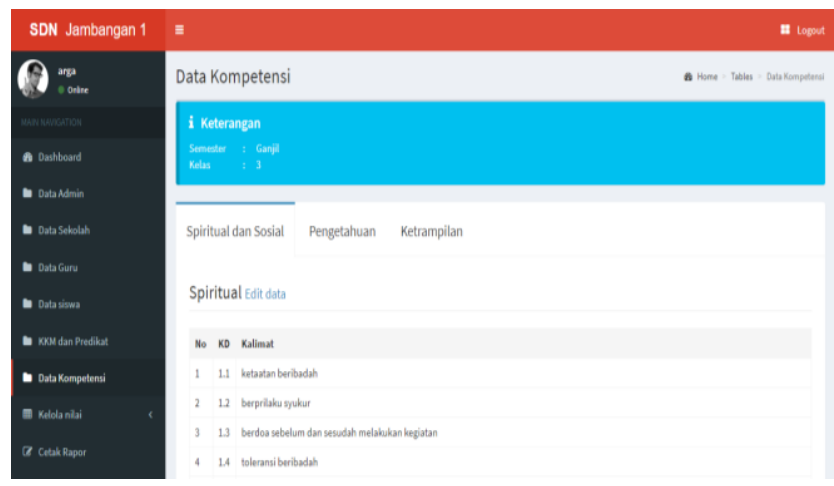

Gambar 12. Menu Data Kompetensi.

\section{9) Menu Kelola Nilai}

Menu ini terbagi menjadi empat sub-menu yaitu sub-menu masukkan nilai, sub-menu lihat nilai, sub-menu ekstrakurikuler, sub-menu prestasi dan saran. Pada sub-menu masukkan nilai terdapat tombol download format nilai yang digunakan untuk mengunduh dokumen Excel sebagai acuan memasukkan nilai siswa dan tombol upload untuk memasukkan dokumen Excel yang berisi nilai siswa kedalam sistem. Sub-menu lihat nilai difungsikan untuk menampilkan 
nilai siswa yang telah dimasukkan. Sub-menu ekstrakurikuler dan sub-menu prestasi dan saran digunakan untuk menampilkan kalimat nilai ekstrakurikuler, kalimat nilai prestasi serta saran dari wali kelas untuk siswa. Tampilan menu Kelola Nilai ditampilkan pada Gambar 13.

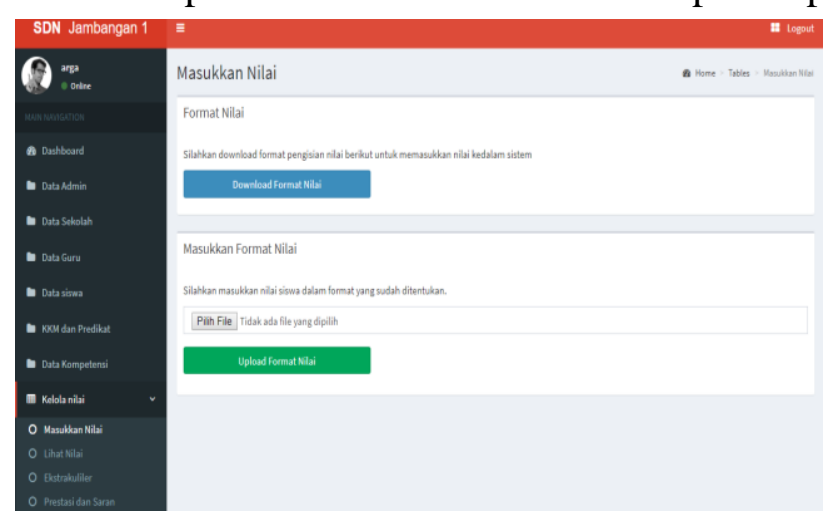

Gambar 13. Menu Kelola Nilai.

10) Menu Cetak Rapor

Menu Cetak Rapor merupakan tampilan yang digunakan untuk mencetak rapor siswa. Tampilan Menu Cetak Rapor disajikan pada Gambar 14.

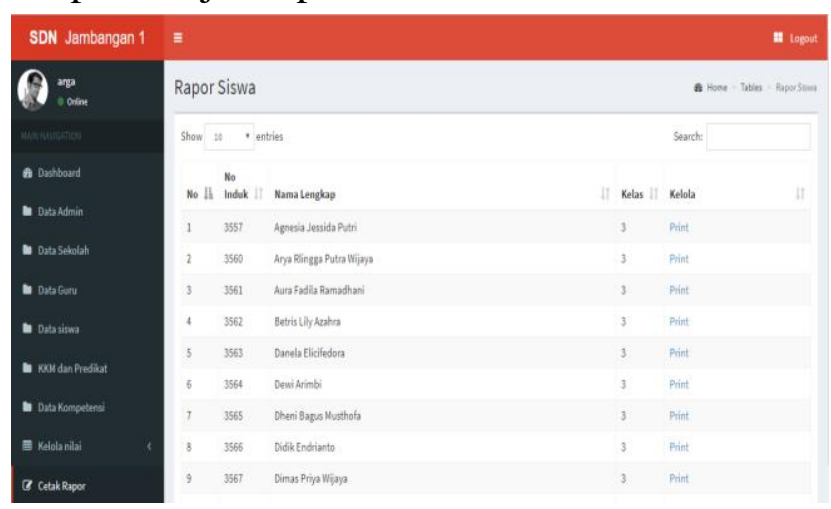

Gambar 14. Menu Cetak Rapor.

\section{b. Pengujian Sistem}

\section{1) Black Box Testing}

Black Box Testing atau Pengujian black box merupakan pengujian yang menitikberatkan pada fungsionalitas sistem. Pengujian ini bertujuan untuk memvalidasi sistem agar dapat bekerja sesuai dengan fungsional yang sudah direncanakan. Hasil pengujian black box pada sistem ini ditampilkan dalam Tabel 1.

Tabel 1. Hasil Pengujian Black Box.

\begin{tabular}{|c|c|c|c|c|}
\hline No. & Menu & Aspek yang diuji & Hasil yang diharapkan & Kesimpulan \\
\hline \multirow{2}{*}{1.} & \multirow{2}{*}{ Menu Login } & $\begin{array}{l}\text { Memasukkan username } \\
\text { dan password yang benar }\end{array}$ & Masuk ke halaman utama & Valid \\
\hline & & $\begin{array}{l}\text { Memasukkan username } \\
\text { dan password yang salah }\end{array}$ & $\begin{array}{l}\text { Gagal masuk ke halaman } \\
\text { utama }\end{array}$ & Valid \\
\hline 2. & $\begin{array}{l}\text { Menu Data } \\
\text { Admin }\end{array}$ & $\begin{array}{l}\text { Melakukan } \\
\text { pengoperasian CRUD } \\
\text { data admin }\end{array}$ & $\begin{array}{l}\text { Data admin dapat ditambah, } \\
\text { ditampilkan pada form, } \\
\text { diubah dan dihapus }\end{array}$ & Valid \\
\hline 3. & $\begin{array}{l}\text { Menu Data } \\
\text { Sekolah }\end{array}$ & $\begin{array}{l}\text { Melakukan } \\
\text { pengoperasian CRUD } \\
\text { data sekolah }\end{array}$ & $\begin{array}{l}\text { Data sekolah dapat } \\
\text { ditambah, ditampilkan pada } \\
\text { form, diubah dan dihapus }\end{array}$ & Valid \\
\hline
\end{tabular}




\begin{tabular}{|c|c|c|c|c|}
\hline 4. & $\begin{array}{l}\text { Menu Data } \\
\text { Guru }\end{array}$ & $\begin{array}{l}\text { Melakukan } \\
\text { pengoperasian CRUD } \\
\text { data guru }\end{array}$ & $\begin{array}{l}\text { Data guru dapat ditambah, } \\
\text { ditampilkan pada form, } \\
\text { diubah dan dihapus }\end{array}$ & Valid \\
\hline 5. & $\begin{array}{l}\text { Menu Data } \\
\text { Siswa }\end{array}$ & $\begin{array}{l}\text { Melakukan } \\
\text { pengoperasian CRUD } \\
\text { data siswa }\end{array}$ & $\begin{array}{l}\text { Data siswa dapat ditambah, } \\
\text { ditampilkan pada form, } \\
\text { diubah dan dihapus }\end{array}$ & Valid \\
\hline 6. & $\begin{array}{l}\text { Menu KKM } \\
\text { dan } \\
\text { Predikat }\end{array}$ & $\begin{array}{l}\text { Melakukan } \\
\text { pengoperasian CRUD } \\
\text { data KKM dan Predikat }\end{array}$ & $\begin{array}{l}\text { Data KKM dan predikat } \\
\text { dapat ditambah, } \\
\text { ditampilkan pada form, } \\
\text { diubah dan dihapus }\end{array}$ & Valid \\
\hline 7. & $\begin{array}{l}\text { Menu Data } \\
\text { Kompetensi }\end{array}$ & $\begin{array}{l}\text { Melakukan } \\
\text { pengoperasian CRUD } \\
\text { data kompetensi }\end{array}$ & $\begin{array}{l}\text { Data Kompetensi dapat } \\
\text { ditambah, ditampilkan pada } \\
\text { form, diubah dan dihapus }\end{array}$ & Valid \\
\hline \multirow{4}{*}{8.} & \multirow{4}{*}{$\begin{array}{l}\text { Menu } \\
\text { Kelola Nilai }\end{array}$} & $\begin{array}{l}\text { Melakukan operasi } \\
\text { penginputan nilai siswa }\end{array}$ & $\begin{array}{l}\text { Data nilai siswa dapat } \\
\text { ditambahkan ke dalam } \\
\text { sistem }\end{array}$ & Valid \\
\hline & & $\begin{array}{l}\text { Melakukan } \\
\text { pengoperasian CRUD } \\
\text { data nilai siswa }\end{array}$ & $\begin{array}{l}\text { Data nilai siswa dapat } \\
\text { ditambah, ditampilkan pada } \\
\text { form, diubah dan dihapus }\end{array}$ & Valid \\
\hline & & $\begin{array}{l}\text { Melakukan } \\
\text { pengoperasian CRUD } \\
\text { data Ekstrakurikuler }\end{array}$ & $\begin{array}{l}\text { Data ekstrakurikuler dapat } \\
\text { ditambah, ditampilkan pada } \\
\text { form, diubah dan dihapus }\end{array}$ & Valid \\
\hline & & $\begin{array}{l}\text { Melakukan } \\
\text { pengoperasian CRUD } \\
\text { data prestasi dan saran }\end{array}$ & $\begin{array}{l}\text { Data prestasi dan saran } \\
\text { dapat ditambah, } \\
\text { ditampilkan pada form, } \\
\text { diubah dan dihapus }\end{array}$ & Valid \\
\hline 9. & $\begin{array}{l}\text { Menu Cetak } \\
\text { Rapor }\end{array}$ & $\begin{array}{l}\text { Melakukan operasi cetak } \\
\text { nilai }\end{array}$ & $\begin{array}{l}\text { Menampilkan tampilan } \\
\text { rapor yang siap dicetak }\end{array}$ & Valid \\
\hline
\end{tabular}

2) User Acceptance Testing (UAT)

Pengujian UAT ini dilakukan dengan metode pemberian kuesioner yang berisi delapan pernyataan

yang kemudian diisi oleh 8 responden yatu satu orang admin, satu orang kepala sekolah, dan 6 orang guru wali kelas. Masing-masing pernyataan memiliki lima respon. Respon pertama yaitu Sangat Setuju (SS) memiliki nilai 5, kedua yaitu Setuju (S) dengan nilai 4, ketiga yaitu Netral (N) dengan nilai 4, keempat yaitu Tidak Setuju (TS) dengan nilai 2 dan terakhir yaitu Sangat Tidak Setuju (STS) dengan nilai 1.

Hasil dari kuesioner tersebut kemudian berguna untuk menghitung persentase jawaban. Perhitungan menggunakan rumus persentase jawaban yang ditunjukkan pada Persamaan 1.

Persentase $=\frac{\text { Jumlah Skor }}{\text { Jumlah maksimal }} \times 100 \%$

Tabel 2. Hasil pengujian UAT beserta persentasenya.

\begin{tabular}{|l|l|c|c|c|c|c|c|c|}
\hline \multirow{2}{*}{ No. } & \multicolumn{1}{|c|}{ Pernyataan } & \multicolumn{3}{|c|}{ Responsi } & \multicolumn{2}{c|}{$\begin{array}{c}\text { Jumlah } \\
\text { responden }\end{array}$} & Persentase \\
\cline { 2 - 8 } & SS & S & N & KS & STS & respong \\
\hline 1. & $\begin{array}{l}\text { Sistem ini memiliki tampilan yang } \\
\text { menarik. }\end{array}$ & 7 & 1 & - & - & - & 8 & $97,5 \%$ \\
\hline
\end{tabular}




\begin{tabular}{|l|l|c|c|c|c|c|c|r|}
\hline 2. & $\begin{array}{l}\text { Sistem ini memiliki tampilan menu sesuai } \\
\text { dengan yang diharapkan. }\end{array}$ & 5 & 3 & - & - & - & 8 & $92,5 \%$ \\
\hline 3. & $\begin{array}{l}\text { Semua menu di sistem ini berfungsi } \\
\text { dengan baik. }\end{array}$ & 6 & 2 & - & - & - & 8 & $95 \%$ \\
\hline 4. & $\begin{array}{l}\text { Sistem ini mudah dimengerti dan mudah } \\
\text { untuk digunakan. }\end{array}$ & 6 & 2 & - & - & - & 8 & $95 \%$ \\
\hline 5. & $\begin{array}{l}\text { Sistem ini memudahkan pihak sekolah } \\
\text { dalam mengelola dan mengolah data nilai } \\
\text { siswa. }\end{array}$ & 8 & - & - & - & - & 8 & $100 \%$ \\
\hline 6. & $\begin{array}{l}\text { Sistem ini dapat mempercepat } \\
\text { pengelolaan dan pengolahan data nilai } \\
\text { siswa. }\end{array}$ & 8 & - & - & - & - & 8 & $100 \%$ \\
\hline 7. & $\begin{array}{l}\text { Tampilan rapor di sistem ini sudah sesuai } \\
\text { dengan kebutuhan sekolah. }\end{array}$ & 6 & 2 & - & - & 8 & $95 \%$ \\
\hline
\end{tabular}

Hasil pengujian UAT yang sudah dilaksanakan menunjukkan bahwa pernyataan pertama yaitu Sistem ini memiliki tampilan yang menarik menghasilkan persentase sebesar 97,5\%, pernyataan kedua Sistem ini memiliki tampilan menu sesuai dengan yang diharapkan menghasilkan persentase sebesar 92,5\%, pernyataan ketiga Semua menu di sistem ini berfungsi dengan baik menghasilkan persentase sebesar 95\%, pernyataan keempat Sistem ini mudah dimengerti dan mudah untuk digunakan menghasilkan persentase sebesar 95\%, pernyataan kelima Sistem ini memudahkan pihak sekolah dalam mengelola dan mengolah data nilai siswa menghasilkan persentase sebesar 100\%. pernyataan keenam Sistem ini dapat mempercepat pengelolaan dan pengolahan data nilai siswa menghasilkan persentase sebesar $100 \%$. pernyataan ketujuh Tampilan rapor di sistem ini sudah sesuai dengan kebutuhan sekolah menghasilkan persentase sebesar 95\%. Kesimpulan yang didapat dari pengujian ini yaitu $96,42 \%$ responden menyetujui bahwa sistem ini dapat memudahkan dan mempercepat pengelolaan data nilai siswa.

\section{KESIMPULAN}

Berdasarkan pengujian Black Box, Sistem Informasi Pengelolaan Data Nilai Siswa pada SDN Jambangan 1 sudah bekerja sesuai fungsionalitas. Berdasarkan pengujian User Acceptance Testing (UAT) memperoleh rata-rata persentase sebesar 96,42\%. Kesimpulan yang didapat yaitu sistem ini dapat membantu pihak sekolah dalam mengelola dan mengolah data nilai siswa. Selain itu sistem ini dapat dioperasikan dengan mudah sehingga dapat mempercepat pihak sekolah dalam pengelolaan dan pengolahan data nilai siswa.

\section{SARAN}

Sistem informasi ini memiliki beberapa kekurangan diantaranya pada fungsi export nilai masih membutuhkan waktu yang lama untuk mengunduhnya sehingga diharapkan untuk bisa diefisienkan. Dari hasil pengujian UAT, tampilan menu sistem memiliki persentase paling kecil sehingga diharapkan tampilan menu sistem agar diatur lebih menarik lagi.

\section{DAFTAR PUSTAKA}

[1] Rivai, D.A. and Purnama, B.E., 2013. Pembangunan sistem informasi pengolahan data nilai siswa berbasis web pada Sekolah Menengah Kejuruan (SMK) Miftahul Huda Ngadirojo. IJNS-Indonesian Journal on Networking and Security, 3(2). 
[2] Wardani, S.K., 2013. Sistem Informasi Pengolahan Data Nilai Siswa Berbasis Web Pada Sekolah Menengah Atas (SMA) Muhammadiyah Pacitan. IJNS-Indonesian Journal on Networking and Security, 2(2).

[3] Rosa, A.S. and Shalahuddin, M., 2015. Rekayasa perangkat lunak terstruktur dan berbasis objek. Bandung: Informatika.

[4] Puspitasari, D., 2016. Sistem Informasi Perpustakaan Sekolah Berbasis Web. Jurnal Pilar Nusa Mandiri, 12(2), pp.227-240.

[5] Isa, I.G.T. and Hartawan, G.P., 2017. Perancangan Aplikasi Koperasi Simpan pinjam Berbasis Web (Studi Kasus Koperasi Mitra Setia). Jurnal Ilmiah Ilmu Ekonomi (Jurnal Akuntansi, Pajak dan Manajemen), 5(10), pp.139-151.

[6] Kurniawan, A., Harefa, B.B. and Sujarwo, S., 2014. Unified Modeling Language Tools Collaboration for Use Case, Class and Activity Diagram Implemented with HTML 5 and Javascript Framework. Journal of Computer Science, 10(8), p.1440.

[7] Munassar, N.M.A. and Govardhan, A., 2010. A comparison between five models of software engineering. International Journal of Computer Science Issues (IJCSI), 7(5), p.94.

[8] Alshamrani, A. and Bahattab, A., 2015. A comparison between three SDLC models waterfall model, spiral model, and Incremental/Iterative model. International Journal of Computer Science Issues (IJCSI), 12(1), p.106.

[9] Kumar, M., Singh, S.K. and Dwivedi, R.K., 2015. A Comparative Study of Black Box Testing and White Box Testing Techniques. International Journal of Advance Research in Computer Science and Management Studies, 3(10), pp.32-44.

[10] Otaduy, I. and Díaz, O., 2017. User acceptance testing for Agile-developed web-based applications: Empowering customers through wikis and mind maps. Journal of Systems and Software, 133, pp.212-229.

[11]Bassil, Y., 2012. A simulation model for the waterfall software development life cycle. arXiv preprint arXiv:1205.6904.

[12]Bergmane, L., Grabis, J. and Žeiris, E., 2017. A Case Study: Software Defect Root Causes. Information Technology and Management Science, 20(1), pp.54-57.

[13] Kumar, P. and Khan, R.A., 2015. Classification of Software Requiremnt Errors: A Critical Review. International Journal of Computer Applications, 132(7), pp.9-14. 